\title{
The Relationship between Eco-Innovation and Business Performance in Mexican SMEs
}

\author{
Sandra Yesenia Pinzón Castro \\ Universidad Autónoma de Aguascalientes \\ Centro de Ciencias Económicas y Administrativas \\ Departamento de Mercadotecnia \\ Mexico \\ Gonzalo Maldonado Guzmán \\ Universidad Autónoma de Aguascalientes \\ Centro de Ciencias Económicas y Administrativas \\ Departamento de Mercadotecnia \\ Mexico
}

\begin{abstract}
Eco-innovation is a relatively recent construct in the literature of marketing, and is gaining more and more importance among researchers, academics and professionals who consider it as an important construct that generates the companies that have adopted and implemented more and better results business, including a higher level of business performance. However, most of the studies published in the current literature have focused on large international companies, and few studies have focused on the analysis of the relationship between eco-innovation and business performance in small companies. Therefore, using a sample of 300 small companies in the manufacturing industry, the essential objective of this empirical study is the analysis and discussion of the effects exerted by eco-innovation on the business performance of SMEs in the manufacturing industry. The results obtained show that eco-innovation has a significant positive effect on the level of business performance of SMEs in the manufacturing industry.
\end{abstract}

Keywords: Innovation, open innovation, business performance, financial performance.

\section{Introduction}

Eco-innovation has become one of the most demanded constructs in the literature of business and management sciences because it allows enterprises to improve significantly their innovation skills (Kemp et al. 1992). To be more precise, enterprises that aim to improve their organization skills such as the reduction of resources, recycling, pollution prevention, the design and sale of environmentally friendly products, tend to adopt and implement eco-innovation activities (Georg et al., 1992; Winn \& Roome, 1993; Hsieh et al., 2012). Furthermore, Florida et al. (2001) considered the presence of two essential factors (organizational resources and monitoring systems performance) that enterprises take into consideration for the adoption and implementation of eco-innovation activities.

In this regard, it is possible to establish that the different eco-innovation activities are a combination of processes, new or modified systems, practices, and products that have a positive impact in the environment where the enterprises settle (Silva et al. 2013). Moreover, for the evaluation of the environmental evaluations, the decrease of gas emissions, the use of energy, the pollution of water, air and soil, eco-innovation is becoming one of the most efficient and effective measurements of the new era of the clean production in industries, mostly in small and medium-size enterprises (SMEs), which improves significantly the sustainable operation, competitiveness and business performance of organizations (Belin et al., 2009; Foxon \& Andersen, 2009; Hisieh et al., 2012).

Similarly, according to Carrillo-Hermosilla et al. (2009), the term eco-innovation is being used more and more by researchers, scholars and professionals of business sciences for the analysis of environmental management policies implemented, by enterprises and government authorities in different contexts and situations (Silva et al., 2013), and with a wide range of connotations (Falk \& Ryan, 2006) that have positive and significant effects in business performance (Doran \& Ryan, 2012; Klewitz et al., 2012; Silva et al., 2013). Therefore, it is possible to consider that eco-innovation is based on the perspective of evolution of innovation (Dosi et al., 1988; Arthur, 1994; Nelson \& Winter, 2002; Witt, 2009), in which the innovation is developed through systematic processes that have a strong link and interaction, among the different external and internal factors of the organization (Carrillo-Hermosilla et al., 2009). 
Accordingly, it is important to mention that managers of enterprises, especially those of SMEs, do not normally have an environmental motivation that allows them the adoption and implementation of eco-innovation activities, but when they realize about the environmental and business results obtained by the eco-innovation, their perception changes and they are willing to make changes in the organization for the development of eco-innovation (Edwards-Schachter et al., 2011; Gehani, 2011; Dalmarco et al., 2011; Balbinot et al., 2012; Salami \& Soltanzadeh, 2012). Thus, the benefits for SMEs in the implementation of eco-innovation include the decrease of use of water, emission of pollutants, improvement of environmental conditions, social responsibility and a significant increase in business performance (Weng \& Li, 2011).

In this context, it is advisable to consider that there are relatively few empirical researches that are published, that they focus on the analysis and discussion of the effects of eco-innovation in the level of business performance and that there are even fewer published empirical papers that focus in SMEs. Therefore, the main contribution of this empirical investigation is the analysis and discussion of the relation between eco-innovation activities and business performance of SMES of a country with an emerging economy, as it is the case of Mexico, just as it is recommended by Doran and Ryan (2012), Klewitz et al. (2012) as well as Silva et al. (2013).

\section{Literature Review}

Nowadays, innovation has become one of the main activities of enterprises, especially SMEs, considering that for most of them innovation is one of the essential resources for their survival (Baumol, 2002). Furthermore, most government authorities of the world are designing and implementing different policies and programs aimed to decrease the emission of pollutants and climate change. In order to do so, one of the best options to achieve these goals is to put into practice eco-innovation activities in enterprises from all sectors and sizes (Doran \& Ryna, 2012), because through the different eco-innovation activities the enterprises develop or adapt innovations with the diagnostic, monitoring, decrease or prevention of the main environmental problems that affect the economy and society (Hemmelskamp, 1997).

In this regard, Kemp and Andersen (2004) considered that eco-innovation can be technical, organizational or marketing innovations that enterprises carry out because for some companies innovation involves only the substitution of some basic substances of their products, whereas other organizations imply that innovation refers to the design and use of control systems of contamination, management of waste and the use of green technologies (Doran \& Ryna, 2012). Similarly, Halila and Rundquist (2011) concluded that eco-innovation promotes the growth and development of the economy of countries, as well as the business performance whereas some conservative economists and managers view eco-innovation as an additional cost for organizations (Ambec et al., 2011).

Nevertheless, for some authors like Porter and van der Linde (1995), the investment in eco-innovation activities can produce a higher level of competitiveness in enterprises, increase significantly the business performance and decrease pollution because for these researchers eco-innovation can create a clear win-win situation with environmental and economic benefits for enterprises of all sizes and sectors. Unfortunately, there is still a high percentage of enterprises, (especially SMEs), that do not usually have the opportunity to attain a win-win situation with eco-innovation activities, which produces low levels of participation in the market where they participate when compared with other types of innovations made in the same organization (Horbach, 2008).

Consequently, different researchers and scholars have discussed that an efficient and effective design of environmental regulations could promote significantly eco-innovation activities in enterprises, especially SMEs (e.g. Porter \& van der Linde, 1995; Halila \& Rundquist, 2011). In this regard, there are more SMEs that are adopting and implementing ecoinnovation activities that contribute to the solution of social problems of sustainable development and the environmental deterioration (Luetkenhorst, 2004; LaPoutre \& Heene, 2006; Jamali et al., 2009). Therefore, ecoinnovation can benefit SMEs by adopting practices of organizational sustainability, such as the drop of costs (e.g. an increase in the efficiency of the use of energy), or the attainment of more or better competitive advantages (e.g. higher probability of success in the innovation of products) (Klewitz et al., 2012).

In this set of ideas, SMEs have to adopt a series of organizational changes both internally and externally in terms of the restriction of resources about time, knowledge, financing and human capital (Pérez-Sánchez et al., 2003; EUC, 2007; Lee, 2009), as well as those factors related to the management and structure of the organization, such as the presence or lack of trained personnel in sustainability management or in the informal administration of the different activities of sustainability (Spence, 1999; Jenkins, 2004). Thus, these changes represent a complex effort for a considerable amount of SMEs, since they need to implement cooperation activities with external organizations such as universities, research institutes, government departments or consulting agencies so they can have access to the knowledge and direct help to improve their sustainability activities (LePoutre \& Heene, 2006; Valliere, 2006; Jenkins, 2009). 
Likewise, it is possible to establish that eco-innovation includes the improvement of processes, products and business practices that reduce significantly the negative impacts in the environment (van Hemel \& Cramer, 2002; Beise-Zee \& Rennings, 2005; Rennings et al., 2006). Consequently, the integration of activities related to sustainability and ecoinnovation can create in SMES a reduction of costs (e.g. through a better management system of energy use), risks (e.g. through an improvement of their safety systems).

An increase in sales and business performance (e.g. through the introduction of organic brands), a rise in the reputation and value of the brand that can be more attractive for employees (e.g. through a better alignment of the values of the staff and the organization), and a higher level of development of the innovation skills (Schaltegger, 2011).

Besides these potential benefits that SMEs can obtain, the activities related to sustainability require the implementation of important changes in the organization (Klewitz et al., 2012). For this, several concepts, instruments and tools have been developed in the literature to support enterprises in their efforts to improve the environment (Schaltegger et al., 2007). However, most of the instruments and tools have been designed to be used by big transnational enterprises, and it is not possible to implement them in SMEs, because this type of organization is not a smaller version of large companies (Welsh \& White, 1981; Tilley, 2000). SMEs need rather other types of tools and different approaches that enable them to improve the efficiency and effectiveness of their environmental activities (Klewitz et al., 2012).

In this regard, the literature makes an emphasis on identifying essential aspects that differentiate SMEs from large enterprises or corporations, and these differences usually refer to specific characteristics or features that SMEs have (Vyakarnam et al., 1997; Spence, 1999; del Brío \& Junquera, 2003). Moreover, several researchers and scholars in recent published investigations in the literature of business sciences have tried to explain the characteristics that, in the context of sustainability of SMEs, allow a better integration of the essential activities of the organizations with better business results (e.g. Spence, 1999; Spence \& Lozano, 2000; Spence \& Rutherfoord, 2001; Schaper \& Savery, 2004; Jenkins, 2004; Moore \& Spence, 2006; Preuss \& Perschke, 2010).

To sum up, the published investigations in the current literature establish that the characteristics of SMEs create advantages and disadvantages, that have a strong influences in the integration of the sustainability and eco-innovation activities (Klewitz et al., 2012). The characteristics that give SMEs more advantages are the informal media; the flexibility of their processes and the organizational structure (Bos-Brouwers, 2009), since these features allows SMEs to lessen the bureaucratic management in sustainability and eco-innovation activities. Similarly, the entrepreneurship and role of managers, who are usually the owners of SMEs, have a positive effect in the quick reaction to changes demanded by the market where they participate which facilitates the innovation of the products required by consumers (Jenkins, 2006).

Conversely, there are some singularities of SMEs that create disadvantages when compared with big enterprises. One of them, and perhaps the most important one, is the difficulty in the implementation of changes for the development of the different activities regarding eco-innovation (del Brío \& Junquera, 2003). It is even more complicated the implementation of eco-innovation (Luetkenhorst, 2004; Jenkins, 2006, 2009; Sweeney, 2007; Russo \& Tencati, 2009). That is why maybe the lack of resources, the lack of trained personnel, low knowledge of the staff and the scarce of financial capital (Azzone \& Noci, 1998; Spence, 1999; del Brío \& Junquera, 2003; Bos-Brouwers, 2009), could be the basic elements that limit both the investment and the implementation of eco-innovation activities in SMEs (Noci \& Verganti, 1999).

Regardless of these setbacks in SMEs, it is possible that eco-innovation can be implemented in this type of enterprises but their level of development is different since such development is more probable in those companies that are more reactive, proactive or with a clear innovation strategy (Noci \& Verganti, 1999). Thus, according to del Brío and Junquera (2003), SMEs in general tend to be more reactive than proactive in the management of sustainability and innovation, which can produce low levels or business performance (Scozzi et al., 2005). As a result of this reactive capacity, SMEs tend to carry out more incremental innovations in their products rather than radical innovations (del Brío \& Junquera, 2003), which reduce significantly the business results obtained.

Moreover, most SMEs are regarded as micro-enterprises that have ten or less employees (Klees, 2008; Census, 2011), which complicate even more the implementation of eco-innovation activities (Bennett et al., 2011), as well as an advanced training of their employees (Kotey \& Folker, 2007), and the efficiency of management with their main trading partners (Klewitz et al., 2012). As a result, it is possible to establish that SMEs generally have a higher capacity of being reactive to the adversities, that may happen including sustainability and eco-innovation activities which allow them to adopt and implement adequately, based on their capacity, eco-innovation activities and creating with this positive and significant effects in their level of business performance (Suh et al., 2005). 
Additionally, the actions taken by SMEs in the improvement of the environment and sustainability will have positive and significant effects in their business performance even when their actions are reactive (Klewitz et al., 2012). That is why these actions will have a higher economic value of the products of SMEs, by creating a smaller impact in the environment (Callens \& Tyteca, 1999; Figge \& Hahn, 2002). Consequently, their eco-innovation activities will be more eco-efficient (Schaltegger \& Sturm, 1990; Dyllick \& Hockerts, 2002).

Therefore, eco-innovation will allow SMEs to reduce the environmental impact produced by their business activities, the increase of economic value of their products and the rise of their business performance with a low level of environmental impact (Schaltegger \& Sturm, 1990; Schmidheiny, 1992).

Likewise, eco-innovation in SMEs can be measured through different actions such as the reduction of energy and water use, the efficiency in resources, the use of raw materials, the waste management and the intensity of pollution (von Weizsaecker et al., 1997; Verfaille \& Bidwell, 2000). Furthermore, eco-innovation can be applied to all types of innovation that SMEs create: processes (production of environmentally friendly goods and services), products (more efficient products), and management systems (reorganization of structures or the implementation of new management tools) (Rennings, 2000; Rennings et al., 2006). This could improve not only all types of innovation of SMEs (Ar \& Baki, 2011), but also their level of business performance (Bigliardi et al., 2011; Doran \& Ryan, 2012; Klewitz et al., 2012; Silva et al., 2013). Therefore, considering the information presented above, it is possible to establish the following research hypothesis.

\section{H1: The higher level of eco-innovation, higher level of business performance}

\section{Methodology}

An empirical research of SMEs in Aguascalientes (Mexico) was carried out in order to answer the hypothesis established, by using the business directory of the Sistema de Información Empresarial Mexicano (System of Mexican Business Information, or SIEM) from Aguascalientes State which had 1,527 registered enterprises, each one containing from 5 to 250 workers at the end of July. Moreover, an instrument of data collection regarding eco-innovation activities and business performance was designed to be answered by managers and/or owners of SMEs. It was carried out as a personal interview with a sample of 300 enterprises selected through a random sampling with a maximum error of $\pm 5 \%$ and a level of reliability of 95\%, which took place between March and July of 2018.

\section{Dependent variable}

The scale used for the measurement of eco-innovation was proposed by Segarra-Oña et al. (2014), who made an adaptation of the scale developed by Doran and Ryan (2012), and they considered that eco-innovation can be measured through 14 items. Based on the answers, the variable Eco-innovation was built through the median of all the 14 items that integrated the scale. Moreover, all the items of the eco-innovation scale were measured through a Likert-type scale of five positions from " $1=$ completely agree" to " $5=$ completely disagree" as limits.

\section{Independent and control variables}

The scale used for the measurement of business performance was proposed by Leonidou et al. (2013), who considered that business performance can be measured through 7 items. Similarly, based on the answers, the variable Performance was built through the median of all the 7 items that integrated the scale of business performance. Furthermore, all the items of the business performance scale were measured through a Likert-type scale of five positions from " $1=$ completely disagree" to " $5=$ completely agree" as limits.

Additionally, two control variables were used (size and years in business), since it is considered in the current literature of business and management sciences that these variables can also have positive and significant effects. Such variables were organized in the following way:

Size. This variable was measured through the average number of employees in 2008 (Micro, Small and Medium size)

Years in business. It was measured through the number of years past from the creation or beginning of the activity (Young and Mature Enterprises).

\section{Results}

In order to answer the research hypothesis established in this empirical research and verify the existing relation between eco-innovation activities and the level of business performance of SMEs, a linear regression analysis was carried out through the ordinary least squares (OLS) by using the following model approach:

\section{Performance $_{i}=b_{0}+b_{1} \cdot$ Eco-innovation ${ }_{i}+b_{2}$ Size $+b_{3}$ Years in business $+\varepsilon_{i}$}

Where Performance ${ }_{i}$ represents the level of business performance obtained by the enterprises that participated in the research. Eco-innovation $i$ corresponds to the adoption and implementation of eco-innovation activities in SMEs. Size, 
the average number of employees, and Years in business, the years the enterprise has existed. The model was estimated in order to know the results (see Table1), and it is possible to observe that the independent variables have a variance inflation factor (VIF) close to 1, which excludes the presence of multicollinearity.

Table 1. Relation of Eco-innovation and Business Performance $(\mathrm{n}=300)$

\begin{tabular}{|l|c|}
\hline \multicolumn{1}{|c|}{ Variables } & Business Performance \\
\hline Eco-innovation & $0.355^{* * *}$ \\
Size & $(5.587)$ \\
& $0.209 * * *$ \\
Years in business & $(3.666)$ \\
& 0.077 \\
Highest VIF & $(1.386)$ \\
F Value & 1.119 \\
$\mathrm{R}^{2}$ Adjusted & $16.974 * * *$ \\
\hline Below each standardized coefficient, between parentheses, value of the statistical t-student. \\
$*=\mathrm{p} \leq 0.1 ; * *=\mathrm{p} \leq 0.05 ; * * * \mathrm{p} \leq 0.01$
\end{tabular}

The results of Table 1 show that a higher use of Eco-innovation in SMEs has a positive and significant influence in their level of business performance (standardized coefficient $=0.355$ and $p<0.01$ ), which confirms the hypothesis established in the research. Moreover, the size has a lower degree of influence (standardized coefficient $=0.209$ and $\mathrm{p}<$ 0.01) in the business performance of SMEs. However, the years in business do not affect the level of business performance, as it is not a statistically significant variable. The validity of the model is contrasted through the $\mathrm{R}^{2}$ adjusted that was 0.384 and with an $F$ value of $16.974(\mathrm{p}<0.01)$. The independent variables have a variance inflation factor $(\mathrm{VIF}=1.119)$ close to 1 , which excludes the presence of multicollinearity.

\section{Conclusions And Discussion}

The results obtained in this empirical research make it possible to conclude about two essential aspects. On one hand, eco-innovation activities are becoming a fundamental need for all enterprises of the different sectors and industries but especially for SMEs. The high level of competitiveness demanded by the market and the globalization of the economy, along with the current pressure of NGOs as well as an important part of consumers that care about the environment and natural resources are pressing SMEs more and more to redirect their strategies or create new ones that lead to the production of goods and services that are environmentally friendly or that their enterprise activities are aimed to the environmental care.

In this regard, it is possible to conclude that eco-innovation appears in the current marketing literature as a strategy and as an alternative so enterprises of all sectors and sizes, especially SMEs, can comply with the requirements of the market and consumers regarding the creation of products or services that are environmentally friendly. Accordingly, eco-innovation will allow SMEs not only to attain more and better competitive advantages than their main competitors but also to increase significantly their level of business performance and the possibility to improve their market position and, especially, the very survival of the organizations.

On the other hand, one of the key business objectives and goals of SMEs is the accomplishment of more and better results which can turn into an increase of their economic resources, that is, a higher business performance. Therefore it is possible to conclude that in order to achieve a significant rise of their level of business performance SMEs have to adopt and implement the activities related to eco-innovation because this will allow them to have the possibility to increase their level of business performance as soon as possible. Otherwise, it will be too complicated that SMEs can reach their objectives and goals in a short term, they could even have less possibilities that their products or services were in demand by their consumers because they are not environmentally friendly.

In general, the results obtained can help to conclude that SMEs that adopt and implement eco-innovation activities not only as a business strategy but rather as part of their day-to-day activities will have more opportunities to achieve their business objectives and goals such as to increase significantly their level of business performance. Consequently, if SMEs are not willing to make the changes needed for the adoption and implementation of eco-innovation activities, 
their future will be uncertain and the growth of the level of business performance will be at stake as well as the very survival of the organization because the pressure exerted by government authorities, NGOs, clients and consumers is increasing every time.

Likewise, the results obtained in this empirical research have several implications that are necessary to be established. The first one states that SMEs do not normally have any certification of national or international environmental regulations and most of them do not comply with the regulations created by the three levels of government authorities. Therefore, before adopting or implementing the different activities related to eco-innovation, SMEs have to fulfill the environmental regulations imposed by the local authorities where they are settled. This will allow them to make the necessary changes or modifications so all the organization staff can get used to the work required for the development of eco-innovation activities.

A second implication obtained from these results is that in a high percentage of SMEs established in developing countries with an emerging economy, as it is the case of Mexico, the innovation activities are practically oriented to the implementation of some changes or improvements of existing products in the organization (incremental innovation) whereas only a small amount of SMEs develop new products constantly (radical innovation). However, the modifications or enhancements made by SMEs to their products usually have a high level of acceptance from their clients and consumers. This is not only because they adapt to their preferences and needs but also because most of the times there is a customization of the products, which creates a higher level of business performance.

A third implication of these results is that managers and/or owners of SMEs have to create the necessary and ideal working conditions so the eco-innovation activities can be developed inside the organization. Therefore, this working environment will have to motivate all staff to get involved in eco-innovation activities, which will make all the staff to express their ideas freely regarding the eco-innovation of products created by SMEs. It will also make the personnel to work as a team and find a solution together to the potential problems faced by the organization, which will increase the possibility of improving significantly their level of business performance.

A fourth implication obtained from these results is that managers and/or owners of SMEs also have to involve all the departments or functional areas of the organization in the adoption and implementation of eco-innovation activities in a way that they do not only fulfill the environmental regulations established by the government authorities of the community where the enterprises are settled but also that the information of the changes or improvements demanded by the market and consumers of the products is available for everybody and the staff of all the organization has the necessary information to suggest the modifications or enhancements (i.e. eco-innovation) to such products in order to have more possibilities to achieve a significant increase in the level of business performance.

A fifth and final implication obtained from these results is that managers and/or owners of SMEs will have to carry out training and instruction programs that are necessary for both employees and workers in all the activities related to ecoinnovation that facilitate their development and efficiency because they will determine in a high percentage that all the organization staff has the necessary knowledge and skills to work in the eco-innovation activities and, consequently, the increase of the level of business performance. Otherwise, it would more difficult to attain the results expected from the adoption and implementation of eco-innovation including the rise of business performance.

By contrast, this empirical research also has some limitations that are necessary to establish at this point. The first one is about the sample used as only small and medium size enterprises that had between five and 250 workers were considered. That is why future investigations would have to consider in the sample small enterprises with less than five workers, which represent a little over $60 \%$ of all SMEs in order to confirm the results obtained. The second limitation is that the instrument applied to collect the data only considered SMEs in the state of Aguascalientes (Mexico). Further researches will need to apply the same instrument to other states of the country and even other countries of Latin America in order to verify the results obtained.

A third limitation is the scales used to measure eco-innovation and business performance as they took into consideration only scales with qualitative variables. That is why future investigations will need to consider the use of other type of scales or hard data to validate the results obtained. Finally, a fourth limitation is that the instrument to collect data only considered managers and/or owners of small enterprises. This created the assumption that these executives have a deep understanding about eco-innovation activities and business performance that take place in the enterprises. Future research papers will need to apply the same questionnaire to all the organization staff or their main business partners as well as consumers in order to prove the results obtained. 


\section{Refrénense}

Ambec, S., Cohen, M.A., Elgie, S., \& Lanoie, P. (2011). The Porter hypothesis at 20: Can environmental regulation enhance innovation and competitiveness? Discussion Paper, Resources for the Future, Washington, D.C.

Ar, I., \& Baki, B. (2011). Antecedents and performance impacts of product versus process innovation: Empirical evidence from SMEs located in Turkish science and technology parks. European Journal of Innovation Management, 14(2), 172-206.

Arthur, W.B. (1994). Increasing Returns and Path Dependence in the Economy. Ann Arbor: University of Michigan Press.

Azzone, G., \& Noci, G. (1998). Seeing ecology and green innovations as a source of change. Journal of Organizational Change Management, 11(2), 94-111.

Balbinot, Z., Díaz, J.C., \& Souza, R.B. (2012). Unique organizational competencies of Brazilian technological innovation centers. Journal of Technology Management Innovation, 7(1), 1-16.

Baumol, W. (2002). The Free-Market Innovation Machine: Analyzing the Growth Miracle of Capitalism. Princeton, NJ: Princeton University Press.

Beise-Zee, M., \& Rennings, K. (2005). Lead markets and regulation: A framework for analyzing the international diffusion of environmental innovation. Ecological Economics, 52(1), 5-17.

Belin, J., Horbach, J., \& Oltra, V. (2009). Determinants and specificities of eco-innovations: An econometric analysis for France and Germany based on the Community Innovation Survey. DIME Workshop on Environmental Innovation, Industrial Dynamics and Entrepreneurship, Utrecht University, Germany.

Bennett, M., Schaltegger, S., \& Zvezdov, D. (2011). Exploring the corporate practice of sustainability accounting. In Csutora, M. and Kerekes, S. (Eds.), Accounting for Climate Change - What and How to Measure. Budapest: AULA.

Bos-Brouwers, H. (2009). Corporate sustainability and innovation in SMEs: Evidence of themes and activities in practice. Business Strategy and the Environment, 19(7), 417-435.

Callens, T., \& Tyteca, D. (1999). Towards indicators of sustainable development for firms: A productive efficiency perspective. Ecological Economics, 28(1), 41-53.

Carrillo-Hermosilla, J., del Río, P., \& Könnola, T. (2009). Eco-innovation. When Sustainability and Competitiveness Shake Hands. London: Palgrave.

Census (2011). Statistics about businesses size (including small business) from the US census bureau. Available at: www.censur.gov/econ/smallbus.html.

Dalmacro, G., Dewes, M.F., Zawislak, P.A., \& Padula, A.D. (2011). Universities' intellectual property: Path for innovation or patent competition? Journal of Technology Management Innovation, 6(3), 159-170.

del Brío, J., \& Junquera, B. (2003). A review of the literature on environmental innovation management in SMEs: Implications for public policies. Technovation, 23(12), 939-948.

Doran, J., \& Ryan, G. (2012). Regulation and firm perception, eco-innovation and firm performance. European Journal of Innovation Management, 15(4), 421-441.

Doran, J., \& Ryan, G. (2012). Regulation and firm perception, eco-innovation and firm performance. European Journal of Innovation Management, 15(4), 421-441-

Dosi, G., Freeman, C., Nelson, R., Silverberg, G., \& Soete, L. (1988). Technical Change and Economy Theory. London: Printer.

Dyllick, T., \& Hockerts, K. (2002). Beyond the business case for corporate sustainability. Business Strategy and the Environmental, 11(2), 130-141.

Edwards-Schachter, M., Castro-Martínez, E., \& Lucio, F.I. (2011). International cooperation between firms on innovation and R\&D: Empirical evidence from Argentina and Spain. Journal of Technology Management Innovation, 6(3), 126-147.

European Commission (EUC) (2007). Commitment to Society by Small and Medium-Sized Enterprises in GermanyCurrent Situation and Future Development. Paris: GILDE GmbH.

Falk, J., \& Ryan, C. (2006). Investing a sustainable future: Australia and the challenge of eco-innovation. Futures, $39(1), 215-219$.

Figge, F., \& Hahn, T. (2002). Sustainable value added: Measuring corporate contributions to sustainability beyond ecoefficiency. Ecological Economics, 48(2), 173-187.

Florida, R., Atlas, M., \& Cline, M. (2001). What makes companies green? Organizational and geographic factors in the adoption of environmental practices. Economic Geographic, 77(3), 209-225.

Foxon, T., \& Andersen, M.M. (2009). The greening of innovation systems for eco-innovation: Towards an evolutionary climate mitigation policy. DRUID Summer Conference Innovation, Strategy and Knowledge. Copenhagen. 
Gehani, R.R. (2011). Individual creativity and the influence of mindful leaders enterprise innovation. Journal of Technology Management Innovation, 6(3), 82-92.

Georg, S., Ropke, I., \& Jorgensen, U. (1992). Clean technology innovation and environmental regulation. Environment Responsibility Economic, 2(6), 533-550.

Graafland, J., Ven van de, B.W., \& Stoffele, N.C. (2003). Strategies and instruments for organizing CSR by small and large businesses in the Netherlands. Journal of Business Ethics, 47(1), 45-60.

Halila, F., \& Rundquist, J. (2011). The development and market success of eco-innovations: A comparative study of eco-innovations and other innovations in Sweden. European Journal of Innovation Management, 14(3), 278302.

Hemmelskamp, J. (1997). Environmental policy instruments and their effects on innovation. European Planning Studies, 5(2), 177-194.

Horbach, J. (2008). Determinants of environmental innovation: New evidence from German panel data sources. Research Policy, 37(1), 163-173.

Hsieh, C.H., Liao, M.Y., Tsai, C.H., Huang, H.L., \& Chung, N.T. (2012). A study of building the crisis prevention model for the innovation development of green marketing: A case of the automotive industry. African Journal of Business Management, 6(7), 2644-2658.

Jamali, D., Zanhour, M., \& Keshishian, T. (2009). Peculiar strengths and relational attributes of SMEs in the context of CSR. Journal of Business Ethics, 87(3), 355-377.

Jenkins, H. (2004). A critique of conventional CSR theory: An SME perspective. How can small and medium enterprises embrace corporate social responsibility? Journal of General Management, 29(4), 37-57.

Jenkins, H. (2006). Small business champions for corporate social responsibility. Journal of Business Ethics, 67(3), 241-256.

Jenkins, H. (2009). A business opportunity model of corporate social responsibility for small and medium-sized enterprises. Business Ethics: A European Review, 18(1), 21-36.

Kemp, R., \& Andersen, M.M. (2004). Strategies for eco-efficiency innovation. Strategy Paper for the Informal Environmental Council Meeting, Maastricht, VROM, Den Haag.

Kemp, R., Olsthoorn, X., Oosterhuis, F., \& Verbruggen, H. (1992). Supply and demand factors of cleaner technologies: Some empirical evidence. Environment Responsibility Economics, 2(1), 614-634.

Klees, S. (2008). Small and medium-sized enterprises in Germany. Available at: www.destatis.de/jetspeed/portal/cms/Sites/destatis/Internet/DE/Navigation/Publikationen/STATmagazini/2008 /Unternehmen2008_8,templateId=renderPrint.psml_nnn=true (Acceded 8 March 2019).

Klewitz, J., Zeyen, A., \& Hansen, E.G. (2012). Intermediaries driving eco-innovation in SMEs: A qualitative investigation. European Journal of Innovation Management, 15(4), 442-467.

Kotey, B., \& Folker, C. (2007). Employee training in SMEs: Effect of size and firm type - family and nonfamily. Journal of Small Business Management, 45(2), 214-238.

LaPoutre, J., \& Heene, A. (2006). Investigating the impact of firm size on small business social responsibility: A critical review. Journal of Small Business Ethics, 67(3), 257-273.

Lee, K. (2009). Why and how to adopt green management into business organizations? The case study of Korean SMEs in manufacturing industry. Management Decision, 47(7), 101-112.

Leonidou, L.C., Leonidou, C.N., Fotiades, T., \& Zeriti, A. (2013). Resources and capabilities as drivers of hotel Green marketing strategy: Implications on competitive advantage and performance. Tourism Management, 35(2), 94110.

Luetkenhorst, W. (2004). Corporate social responsibility and the development agenda: The case for involving small and medium enterprises. Intereconomics, 3(2), 157-166.

Moore, G., \& Spence, L. (2006). Small and medium-sized enterprises \& corporate social responsibility: Identifying the knowledge gaps. Journal of Business Ethics, 67(3), 219-226.

Nelson, R.R. \& Winter, S.G. (2002). Evolutionary theorizing in economics. Journal of Economic Perspective, 16(2), 23-46.

Noci, G., \& Verganti, R. (1999). Managing green product innovation in small firms. R\&D Management, 29(1), 3-15.

Pérez-Sánchez, D., Barton, J., \& Bower, D. (2003). Implementing environmental management in SMEs. Corporate Social Responsibility and Environmental Management, 10(2), 67-77.

Porter, M., \& van der Linde, C. (1995). Toward a new conception of the environment-competitiveness relationship. The Journal of Economic Perspective, 9(4), 97-118.

Preuss, I., \& Perschke, J. (2010). Slipstreaming the large boats: Social responsibility in medium-sized enterprises. Journal of Business Ethics, 92(4), 531-551. 
Rennings, K. (2000). Redefining innovation: Eco-innovation research and the contribution from ecological economics. Ecological Economics, 32(2), 169-186.

Rennings, K., Ziegler, A., Ankele, K., \& Hoffmann, E. (2006). The influence of different characteristics of the EU environmental management and auditing scheme on technical environmental innovations and economics performance. Ecological Economics, 57(1), 45-59.

Russo, A., \& Tencati, A. (2009). Formal vs. informal CSR strategies: Evidence from Italian micro, small, mediumsized, and large firms. Journal of Business Ethics, 85(2), 339-353.

Salami, R., \& Soltanzadeh, J. (2012). Comparative analysis for science, technology and innovation policy: Lessons learned from some selected countries (Brazil, India, China, South Korea and South Africa) for other LdCs like Iran. Journal of Technology Management Innovation, 7(1), 211-227.

Schaltegger, S. (2011). Sustainability as a driver for corporate economics success: Consequences for the development of sustainability management control. Society and Economy, 33(1), 15-28.

Schaltegger, S., \& Sturm, A. (1990). Ecological rationality: Environmentally oriented management instruments. Die Unternehmung, 4(4), 273-290.

Schaltegger, S., Herzig, C., Kleiber, O., Klinke, T., \& Muller, J. (2007). Sustainability Management in Companies from the idea to Practice: Management Concepts to Realize Corporate Social Responsibility and Corporate Sustainability. Berlin: BMU Econsense \& CSM.

Schaper, M., \& Savery, L. (2004). Entrepreneurship and philanthropy: The case of small Australian firms. Journal of Development Entrepreneurship, 9(3), 239-250.

Schmidheiny, S. (1992). Changing Course: A Global Business Perspective on Development and the Environment. Cambridge, MA: MIT Press.

Scozzi, B., Garavelli, C., \& Crowston, K. (2005). Methods for modeling and supporting innovation practices in SMEs. European Journal of Innovation Management, 8(1), 120-137.

Segarra-Oña, M., Peiró-Signes, A., \& Payá-Martínez, A. (2014). Factors influencing automobile firm's eco-innovation orientation. Engineering Management Journal, 26(1), 31-38.

Silva, L.C., Kovaleski, J.L., Gaia, S., Back, L., Szeremeta, M.D., \& Moretti, I.C. (2013). World scenario of green patents: Perspectives and strategies for the development of eco-innovations. African Journal of Business Management, 7(6), 472-479.

Spence, L. (1999). Does size matter? The state of the art in small business ethics. Business Ethics: A European Review, 8(3), 163-174.

Spence, L., \& Lozano, J. (2000). Communicating about ethics with small firms: Experiences from the UK and Spain. Journal of Business Ethics, 27 (1/2), 43-53.

Spence, L., \& Rutherfoord, R. (2001). Social responsibility, profit maximization and the small firm owner-manager. Journal of Small Business and Enterprise Development, 8(2), 126-139.

Suh, S., Lee, K., \& Sangsun, H. (2005). Eco-efficiency for pollution prevention in small to medium-sized enterprises. Journal of Industrial Ecology, 9(4), 223-240.

Sweeney, L. (2007). Corporate social responsibility in Ireland: Barriers and opportunities experienced by SMEs when undertaking CSR. Corporate Governance, 7(4), 516-523.

Tilley, F. (2000). Small firm environmental ethics: How deep do they go? Business Ethics: A European Review, 9(1), $31-41$.

Valliere, D. (2006). Perception of strategic uncertainty: A structural exploration. Journal of Small Business and Entrepreneurship, 19(1), 21-36.

van Hemel, C., \& Cramer, J. (2002). Barriers and stimuli for eco-design in SMEs. Journal of Cleaner Production, 10(5), 439-453.

Verfaille, H., \& Bidwell, R. (2000). Measuring Eco-Efficiency, A Guide to Reporting Company Performance. Geneva: World business Council for Sustainable Development.

von Weizsaecker, E., Lovins, A., \& Lovins, H. (1997). Factor Four - Doubling Wealth, Halving Resource Use. London: Earthscan.

Vyakarnam, S., Bailey, A., Myers, A., \& Burnett, D. (1997). Towards and understanding of ethical behavior in small firms. Journal of Business Ethics, 16(15), 1625-1636.

Welsh, A., \& White, J. (1981). A small business is not a little big business. Harvard Business Review, 4(1), 18-32.

Weng, M.H., \& Lin, C.Y. (2011). Determinants of green innovation adoption for small and medium-size enterprises (SMEs). African Journal of Business Management, 5(22), 9154-9163.

Winn, S.F., \& Roome, N.J. (1993). R\&G management responses to the environment: Current theory and implications to practice and research. $R \& D$ Management, 23(2), 147-160.

Witt, U. (2009). What is specific about evolutionary economics? Journal of Evolutionary Economic, 18(5), 547-575. 